\title{
Modelling the risk of banking system instability in Indonesia using a cross-sectional dependence panel data model
}

\author{
G. Yap \\ Edith Cowan University, School of Accounting, Finance and Economics, Perth, Australia \\ Email: c.yap@ecu.edu.au
}

\begin{abstract}
Since the Asian financial crises in 1997, the Indonesia's banking system has undergone significant transformation. Bank Indonesia has increased the minimum capital requirements for the country's banks; however, its financial system may still be fragile and possibly vulnerable to unexpected macroeconomic shocks. This paper explores the financial health of the Indonesia's banking sector and specifically, we develop a credit risk model containing a set of macroeconomic and bank specific factors. Using a cross-sectional dependence panel data regression, we estimate these factors and determine under which conditions this banking system may be susceptible to financial distress. The paper concludes that macroeconomic fundamentals (i.e. RGDP growth, inflation, stock market performances, net exports and depreciation of domestic currency) and financial soundness (i.e. reserve for money bank deposits and ratio of net foreign assets to GDP) are the factors most likely to influence its stability. Furthermore, bank efficiency can predict banks' credit risk. The study highlights several limitations and future directions for this research topic.
\end{abstract}

Keywords: Banking instability; Credit risk; Macroeconomic shocks; Bank specific; Indonesia 
Yap, G., Modelling the risk of banking system instability in Indonesia using a cross-sectional dependence panel data model

\section{INTRODUCTION}

After the Asian Financial Crises in 1997, Bank Indonesia (BI) launched the Indonesian Banking Architecture (API) on 9 January 2004, a comprehensive basic framework for the Indonesian banking system (Refer to the Bank Indonesia website ${ }^{l}$ ). Its aim is to ensure that the banking structure in Indonesia is sound by requiring a strong capital base for individual banks to withstand risks, improving information system technology and expanding business scale (Goeltom, 2006). Hence, in July 2005, BI issued a regulation on the minimum capital requirements (i.e. IDR100 billion is required for the minimum capital requirement by end-2010) and any bank unable to meet the requirement would lose foreign exchange operations licence and risk closure of branches (Goeltom, 2006).

Nevertheless, the banking system could still be susceptible to unexpected macroeconomic shocks and weak financial management. Evidence shows that banking crises can be preceded by internal and external factors. For the former, Duttagupta and Cashin (2011) found that low bank interest profitability, combined with modest export growth, increases the chances of crisis by over $20 \%$. Furthermore, Bongini et al. (2000) reported that a high share of loan loss reserves in overall capitalization is directly related to distress in financial institutions because the riskiness of their loans increase, causing the the share of net interest income in total income to decline. For the external factors, macroeconomic instability and high foreign exchange risk figure strongly (von Hagen and Ho, 2007). Specifically, Duttagupta and Cashin (2011) estimated that high annual inflation (i.e. greater than $19 \%$ ) combined with relatively low terms of trade growth (i.e. less than $3.25 \%$ ) would increase the risk of a banking crisis from $5.3 \%$ to $21.4 \%$. Elevated foreign exchange risks occur when banks hold a large proportion of deposits in foreign exchange denominated accounts, as the risk of exposure to cross-border lending increases and the banks' balance sheets will deteriorate if the home currencies collapse (Kaminsky, 1999).

Furthermore, Honohan (2000) argued that a banking system failure can be costly with depositors, other creditors and the governments largely paying the bill. He estimated the accumulated resolution costs of bailing out the banking systems for five East Asian crisis countries exceeded \$200 billion. As a banking system deficiency can impact severely on the overall economy, it is imperative to detect early signs of a crisis and impose regulations to ensure that the system is financially 'healthy'.

The Indonesian Government privatized most domestic banks and some evidence suggested that these banks performed well in terms of profit efficiency ${ }^{2}$ (Williams and Nguyen, 2005). Despite the Indonesian government efforts to restructure its bank sector, McLeod (2009) raised several concerns over the country's bank stability. First, many Indonesian banks remained dependent on a government guarantee of banks' liabilities, and second, the government's bailout had imposed a debt burden, which is a loss to the general public and the poor, amounting to at least $40 \%$ of the country's GDP.

Given the evidence above, this study aims to examine the financial healthiness of banking system in Indonesia. In particular, we are interested to explore the risk factors that influence the stability of the banking system.

\section{RELEVANT LITERATURE}

Banking instability arises because many depositors suddenly withdraw a large number of their deposits, thus forcing banks to liquidate their assets to cover operating losses (Diamon and Dybvig, 1983; Dowd, 1992). When banks' deposits and capital are persistently becoming scarce, they have to increase loan costs due to the contraction of credit; subsequently, the borrowers are unable to access loans for investments and consumption (Hoggarth et al., 2002). Depositors' lacking of confidence and declining capital resources provoke financial instability, subsequently causing banking crisis in a country.

Davis and Karim (2008) argued that high levels of non-performing loans can precipitate banking crises due to uncertainty over whether banks can recover losses on loan defaults and protect their depositors' interests. In most instances, banks have to write off these 'bad' loans as losses, and to the worse scenario, they face illiquidity and even bankruptcy.

This research examines to what extent macroeconomic risk factors could adversely affect the stability of Indonesia's banking sector. Our main focus is exploring the factors that facilitate losses due to non-

\footnotetext{
$\begin{array}{lllll}1 & \text { Refer to the Bank Indonesia website for the Indonesia Banking Architecture. } \\ \text { http://www.bi.go.id/web/en/Perbankan/Arsitektur+Perbankan+Indonesia/Struktur+Perbankan/ } & \end{array}$

2 According Williams and Nguyen (2005), profit efficiency refers to the ratio of actual profit to predicted maximum profit.
} 
Yap, G., Modelling the risk of banking system instability in Indonesia using a cross-sectional dependence panel data model

performing loans for all domestic banks in Indonesia. Therefore, we develop a model to measure the probability of non-performance loan losses and adopt loan loss provisions as its proxy, as follows:

$L L P=F\left(L L P_{-1}, M A C, F S, J S C I\right.$, Bank Specific $)$,

where LLP $=$ Loan loss provisions; LLP $_{-1}=$ One period lagged of LLP, MAC $=$ Macroeconomic fundamentals; FS = Financial soundness indicators; JSCI = Jakarta Stock Composite Index; Bank Specific $=$ Bank specific indicators.

The macroeconomic environment is one of the important indicators of a country's financial instability. According to Kalirai and Scheicher (2002), it links to the systematic component of credit risk and it contains information on how a state of business cycle could affect bank lending risks. Furthermore, external liquidity could affect credit risks because banks provide intermediate credit to exporters and hence poor export performance may be detrimental to the banks (Duttagupta and Cashin, 2011). This study also proposes Jakarta Stock Composite Index as an indicator for predicting financial instability in Indonesia. Hadad et al. (n.d.) recommended this index as the proxy for financial market indicator because it has a similar pattern to the cyclical trend of an economy, and they postulated that high stock returns may lower the credit risk. In general, macroeconomic risk factors such as real GDP growth, inflation, interest rates, terms of trade and financial markets are commonly used as the proxy variables for macroeconomic fundamentals.

Financial soundness plays an important role in influencing credit risk (Duttagupta and Cashin, 2011) and it is specifically defined as the strengths and vulnerabilities of a country's financial system (IMF, http://www.imf.org/external/pubs/ft/fsi/guide/2006/pdf/chp2.pdf). Accordingly, a country's financial system is sound if it has a liquid securities market where financial institutions are capable of mobilising funds for investment and providing payment service facilities for financing commercial activities. In the existing literature of banking crises, Duttagupta and Cashin (2011) suggested using banks' exposures to foreign exchange liabilities as one of the indicators of financial soundness to detect banking fragility, as exposure to currency risk would be high if they hold too many foreign currency loans.

In this paper, we replicate and improve the study conducted by Hadad et al. (n.d.) which investigated several macroeconomic factors that influence Indonesia's banking system. The distinct feature of our study is that we also incorporate bank specific variables to determine whether Indonesian banks are capable of controlling the quality of credit (i.e. providing loans to borrowers who have good track records of repaying debts). Such an indicator is important because Indonesia has experienced a history of banking system vulnerability that led to the 1998 Asian Financial Crises and specifically its banks tend to provide risky credits to politically related corporations for reckless non-tradable investments such as shopping malls and real estate (Sheng, 2009). Furthermore, Sheng (2009) argued that since the introduction of banking deregulation in 1988, an increasing number of new private domestic banks had poor governance and insufficient knowledge of banking professional practice. Therefore, the country's financial system could increase its fragility if these new banks do not control the quality of credits. For state-owned banks, Gorton and Winton (1998) warned that they could also be in a position of virtually no bargaining power and inability to control their borrowers (which can be the corrupted government), and therefore, this could increase banks' vulnerability to bankruptcies if large portfolios of nonperforming loans emerge. In general, we hypothesize that when the banks are efficient in monitoring the quality of credits, their loan loss provisions can be reduced. Therefore, this paper includes a cost-to-income ratio as a proxy for bank inefficiency because it measures to what extent a bank may not be able to recover its operating costs given the revenue earned. Furthermore, we include a non-performance asset variable to detect whether the banks would increase their provision for loan losses if there is a rise in loan defaults.

Table 1 summarises the dependent and independent variables used for this paper. It also justifies the reasons of using these variables and the expected signs of the coefficients for each independent variable.

\section{DATA AND METHODS}

In the study, we constructed a panel dataset which consists of 29 domestic banks in Indonesia and a ten-year period from 2001 to 2010. All dependent and independent variables can be obtained from various sources such as Datastream, International Financial Services and Bloomberg. To conduct this empirical analysis, we used dynamic panel regression techniques because they provide more informative data, more variability and more degrees of freedom (Baltagi, 2008). 
Yap, G., Modelling the risk of banking system instability in Indonesia using a cross-sectional dependence panel data model

Table 1. A summary of all dependent and independent variables used

\begin{tabular}{|c|c|c|}
\hline Variable & Name & Description \\
\hline$\frac{F A}{G D P}$ & $\begin{array}{l}\text { Net foreign } \\
\text { assets/gross } \\
\text { domestic } \\
\text { product }\end{array}$ & $\begin{array}{l}\text { This variable is used as a proxy for financial soundness. The net foreign assets variable is the claims on } \\
\text { non-residents (IFS, line 11) less liabilities to non-residents (IFS, line 16c), while the GDP variable is } \\
\text { based on current price. The ratio of net foreign assets to GDP indicates the proportion of foreign assets } \\
\text { owned given domestic goods and services produced by the country. This ratio can be classified as a } \\
\text { liability for a country's financial system because these foreign-owned assets are prone to capital flight. } \\
\text { Data Source: IFS }\end{array}$ \\
\hline INEFFICIENCY & $\begin{array}{l}\text { Cost-to- } \\
\text { Income ratio }\end{array}$ & $\begin{array}{l}\text { This ratio measures to what extent a bank is inefficient. The calculation is as follows: Operating } \\
\text { expenses of a bank are divided by its net income (Net Interest Income + Commission \& Fees Received } \\
+ \text { Other Operating Income + Investment Income - Commissions \& Fees Paid + Taxable Equivalent } \\
\text { Adjustment). If the ratio increases, it shows that the operating cost is high relatively to income, and } \\
\text { there could be a possibility that the bank may experience rising default loans. Data Source: Bloomberg }\end{array}$ \\
\hline $\begin{array}{l}\text { High returns of } \\
\text { JSCI }\end{array}$ & $\begin{array}{l}\text { The highest } \\
\text { returns of } \\
\text { JSCI }\end{array}$ & $\begin{array}{l}\text { This variable measures the peak performance of the stock market in a particular year. When the stock } \\
\text { market performs well, this may imply that the country's economy is sound. Hence, the banks may not } \\
\text { need to increase the provision for loan losses. Data source: Datastream }\end{array}$ \\
\hline INF & Inflation & $\begin{array}{l}\text { It is the annual average inflation rate which indicates the average percentage increase in the price of } \\
\text { goods and services comparing every month of the year with the corresponding month last year. This } \\
\text { variable may be an important indicator because it could influence nominal interest rates and could affect } \\
\text { the ability of borrowers to repay interest on loans. Data source: Euromonitor }\end{array}$ \\
\hline LLP & $\begin{array}{l}\text { Loan loss } \\
\text { provisions }\end{array}$ & $\begin{array}{l}\text { The periodic expense for possible future loan losses. Negative when recoveries are greater than the } \\
\text { allowance made. It is used as proxy for the probability of future losses due to borrowers being unable to } \\
\text { repay loans. Data source: Bloomberg }\end{array}$ \\
\hline $\begin{array}{ll}\text { Low returns of } \\
\text { JSCI }\end{array}$ & $\begin{array}{l}\text { The lowest } \\
\text { returns of } \\
\text { JSCI }\end{array}$ & $\begin{array}{l}\text { It measures the worst performance of the stock market in a particular year. When the stock market } \\
\text { performs badly, it may indicate that the country may experience slow economic growth. Hence, this } \\
\text { could affect the capability of borrowers to repay loans. Given such case, the banks' provision for loan } \\
\text { losses could increase. Data source: Datastream }\end{array}$ \\
\hline RGDP Growth & $\begin{array}{l}\text { Growth in } \\
\text { real gross } \\
\text { domestic } \\
\text { product }\end{array}$ & $\begin{array}{l}\text { The variable measures the growth of all productive activities within a country at a specific year's prices. } \\
\text { In other words, the effects of inflation on GDP are removed by maintaining constant prices. When the } \\
\text { country experiences strong economic growth, borrowers may intend to take out more loans. However, } \\
\text { the remaining question is whether the banks are confident about the capability of the borrowers to repay } \\
\text { the loans. Data source: Euromonitor }\end{array}$ \\
\hline$\Delta \mathrm{BGS}^{\S}$ & $\begin{array}{l}\text { Change in } \\
\text { balance of } \\
\text { goods and } \\
\text { services }\end{array}$ & $\begin{array}{l}\text { The balance of goods and services (BGS) is the difference between exports and imports of goods and } \\
\text { services. If the figures are positive, it indicates positive net exports. It represents the country's export } \\
\text { performance. If the value declines, credit risk would rise because the exporters may not able to repay the } \\
\text { loans. Data source: IFS }\end{array}$ \\
\hline$\Delta \mathrm{LR}^{\S}$ & $\begin{array}{l}\text { Changes in } \\
\text { annual } \\
\text { lending rates }\end{array}$ & $\begin{array}{l}\text { The rates are differentiated according to creditworthiness of borrowers and objectives of financing. } \\
\text { Bank lending rates usually meet the short- and medium term financing needs of the private sector. If the } \\
\text { rate increases, borrowers may encounter rising default risk and that could force the banks to increase } \\
\text { loan loss provision. Data source: IFS }\end{array}$ \\
\hline$\triangle$ MONEYRES $^{\S}$ & $\begin{array}{l}\text { Changes in } \\
\text { reserves of } \\
\text { deposit } \\
\text { money banks }\end{array}$ & $\begin{array}{l}\text { Deposit money banks comprise commercial banks and other banks that accept transferrable deposits } \\
\text { such as demand deposits. It measures the stock of deposit money and it includes all deposits including } \\
\text { assets owned by foreigners. This variable has been adopted by Demiguc-Kun, Detragiache and Gupta } \\
\text { (2006) as a proxy for macroeconomic fundamentals. The authors found that the declining in deposits } \\
\text { can cause banking crises. Hence, in this study, we postulate that if deposit money declines, the banks } \\
\text { have to transfer the burden to borrowers by increasing the lending rates. This could cause some } \\
\text { borrowers failing to repay their loans and hence, the banks would have to increase the probability of } \\
\text { loan losses. Data source: Euromonitor. }\end{array}$ \\
\hline$\overline{E R}$ & Exchange rate & $\begin{array}{l}\text { The variable is the average rate of the Indonesian Ruppiah per US dollar in a particular year. As the } \\
\text { domestic currency depreciates continuously, the country will encounter serious banking crises as a result } \\
\text { of capital flight (see Moshirian and Wu (2009) for more information). It happened to Indonesia during } \\
\text { the } 1998 \text { Asian Financial Crises. Hence, the depreciation of a domestic currency may be an early } \\
\text { indicator of banking instability. Data source: IFS }\end{array}$ \\
\hline$\frac{N P A}{T A}$ & $\begin{array}{l}\text { Non- } \\
\text { performance } \\
\text { assets/total } \\
\text { assets }\end{array}$ & $\begin{array}{l}\text { The variable is the ratio of non-performing assets to total assets. Non-performing assets include loans } \\
\text { that are not currently accruing interest or on which interest is not being paid. They also consist of } \\
\text { renegotiated or restructured loans and other Real Estate Owned (OREO) or foreclosed real estate as well } \\
\text { as troubled debt-restructuring and interest in arrears. A rise in non-performing assets could cause banks } \\
\text { to increase the provision for loan losses. Data source: Bloomberg }\end{array}$ \\
\hline
\end{tabular}

A panel data regression can be written as follows:

$L L P_{i, t}=x_{i t}^{\prime} \beta+e_{i, t}$ 
Yap, G., Modelling the risk of banking system instability in Indonesia using a cross-sectional dependence panel data model

where $L L P_{i, t}=$ Provisions for loan losses from each bank $(i)$ at time $t ; a_{i}=$ individual bank's effect; $x_{i, t}=\mathrm{a}$ vector of independent variables that affect each bank $(i)$ at time $t$ and the first element is 1 ; $e_{i, t}=$ error term for each bank $(i)$ at time $t ; \beta$ is a vector of unknown coefficients.

For the panel regressions, we adopt pooled weighted least squares and fixed effects models with Driscoll and Kraay (1998) (hereafter D-K) standard errors. For simple explanation of a panel regression with D-K standard errors, several OLS assumptions of the error terms in equation (1) are relaxed; that is $e_{i, t}$ is assumed to be autocorrelated, heteroskedastic and cross-sectionally dependent. Hence, D-K standard errors for the estimates are then developed as follows:

$V(\hat{\beta})=\left(X^{\prime} X\right)^{-1} \hat{S}_{T}\left(X^{\prime} X\right)^{-1}$,

where $\hat{S}_{T}=\widehat{\Omega}_{0}+\sum_{j=1}^{m(T)} \omega(j, m)\left[\widehat{\Omega}_{j}+\widehat{\Omega}_{j}^{\prime}\right]$ which incorporate heteroskedasticity, autocorrelation and crosssectional dependence. $m(T)$ denotes the number of lags that the residuals may be serially correlated. $\omega(j, m)=1-j /\{m(T)+1\}$ which are the modified Bartlett weights. The benefits of using D-K standard errors are two-fold. First, it takes into account of cross-sectional dependency and it applies to this study as the banks may demonstrate neighbourhood effects where the decisions made by one bank may influence other banks. Second, the proposed method could be used for small and an unbalanced panel data. Hoechle (2007) modified D-K standard errors in such a way that the regressions can be used for unbalanced dataset. In this research, we discovered that there are missing data and for some banks, we were only able to obtain datasets for the past four years. Hence, given this situation, estimating panel regressions using D-K standard errors may be ideal. For this study, we use STATA statistical software and the program is called 'xtscc'.

\section{EMPIRICAL RESULTS}

Table 2 presents the regression results of pooled data and fixed effects models. Both regressions provide similar findings in terms of coefficient signs and the significance of the variables. From the table, we find that most macroeconomic indicators play an important role in determining the probability of loan default. RGDP growth and inflation are significant and negatively correlated with LLP. This shows that, even if Indonesia experiences strong economic growth and high inflation, the Indonesian banks can be sceptical about the affordability of borrowers to repay their loans. The underlying reason could be that the banks learned the mistakes made from the 1998 Asian financial crises where easy loans were given to politicalrelated corporations for reckless investments during strong economic performance between 1994 and 1996 (Sheng, 2009). Similarly, the variable of net foreign assets to GDP ratio is also found to be positive and statistically significant at the $1 \%$ level. This indicates that if the country holds many foreign assets, individual banks would increase their provisions for loan losses when they anticipate fragility in the country's financial system. In this study, we include two stock market indicators, namely highest and lowest stock returns data, to examine at which stage of stock market performance could affect LLP. Surprising, the results reveal that both high and low stock market returns are important indicators for predicting LLP. Indeed, the coefficient of high returns of JSCI is between 0.66 and 0.69 , which is higher than the coefficient of low returns. Perhaps, even though strong stock market performances could be perceived as a sound economic growth, banks may still take cautious measures to evaluate their borrowers' capabilities of repaying loans. Other indicators such as $\triangle \mathrm{BGS}$ and $\triangle \mathrm{MONEYRES}$ variables have negative signs and significant impacts on LLP. For $\triangle \mathrm{BGS}$, banks could encounter a higher risk of loan default when the country's net export declines possibly due to exporters being unable to sustain their export businesses. Likewise, when reserves for money deposit banks contract, the banks are forced to raise the cost of loans and this could affect the ability of borrowers to repay the loans. If such incidence occurs, there is a high possibility for the banks to increase LLP. Lastly, the findings suggest that depreciation of the domestic currency has a significant influence on LLP. If borrowers use bank loans to purchase assets via currency exchanges, then the depreciation of the domestic currency would affect net worth of the assets and this may pressure the borrowers to declare a loan default.

The table also reveals that one-lagged LLP has a positive and significant impact on current LLP, indicating that the banks may use past information on default loans to project the possible future losses. In fact, the lagged LLP coefficient is 0.744 , implying that the banks are estimated to increase the current LLP by Rp 0.74 billion for every billion of rupiah projected in the previous LLP. In terms of bank specific factors, both regression results suggest that the inefficiency variable significantly influence the LLP. Initially, as the inefficiency variable is calculated as cost-to-income ratio, we hypothesized that the inefficiency and LLP 
Yap, G., Modelling the risk of banking system instability in Indonesia using a cross-sectional dependence panel data model

would be positively correlated and thus we expected a positive sign for the coefficient (see Table 1 for the reason). However, the coefficient sign is negative which is rather difficult to explain and requires further exploration. Furthermore, we found that $\frac{N P A}{T A}$ is statistically insignificant, implying that banks' nonperforming assets do not play an important role in influencing LLP. We expected that higher LLP may be caused by higher non-performance assets, but the current results reveal otherwise.

Table 2. Panel data regressions

\begin{tabular}{|l|l|l|}
\hline \multirow{2}{*}{ Variables } & Dependent variable: LLP \\
\cline { 2 - 3 } & Pooled data regression & Fixed effects regression \\
\hline Constant & $-4.64[0.045]^{* * *}$ & $-3.984[0.175]^{* * *}$ \\
\hline LLP(-1) & $0.744[0.138]^{* * *}$ & $0.459[0.15]^{* * *}$ \\
\hline RGDP Growth & $-0.199[0.038]^{* * *}$ & $-0.245[0.035]^{* * *}$ \\
\hline INF & $-0.029[0.004]^{* * *}$ & $-0.035[0.003]^{* * *}$ \\
\hline FA & $3.731[0.933]^{* * *}$ & $4.328[0.815]^{* * *}$ \\
\hline INEFFICIENCY & & $-0.0001[0.00002]^{* *}$ \\
\hline$\Delta$ BGS & $-0.0001[0.00002]^{* * *}$ & $-0.089[0.009]^{* * *}$ \\
\hline$\Delta$ LR & $-0.057[0.006]^{* * *}$ & $0.201[0.105]^{*}$ \\
\hline$\Delta$ MONEYRES & $0.01[0.141]$ & $-1.48[0.026]^{* * *}$ \\
\hline Low returns of JSCI & $-1.411[0.03]^{* * *}$ & $0.543[0.056]^{* * *}$ \\
\hline High returns of JSCI & $0.44[0.055]^{* * *}$ & $0.66[0.031]^{* * *}$ \\
\hline$N P A$ & $0.696[0.026]^{* * *}$ & $-0.0003[0.0004]$ \\
\hline$T A$ & $-0.001[0.001]$ & $0.0005[0.00001]^{* * *}$ \\
\hline ER & & $0.0006[4.86 \mathrm{e}-06]^{* * *}$ \\
\hline
\end{tabular}

Note: LLP - loan loss provisions; LLP(-1) - one-lagged LLP; RGDP growth - real gross domestic product; INF - inflation rate; $\frac{F A}{G D P}-$ Net foreign assets to GDP; Inefficiency - cost-to-income ratio; BGS - balance of goods and services; LR - annual lending rate; MONEYRES - reserves for money deposits; JSCI - Jakarta Stock Composite Index; $\frac{N P A}{T A}$ - Non-performance assets to Total Assets; ER - rate of currency exchange for Indonesian Rupiah per US dollar. The figures in brackets are Driscoll and Kraay (1998) standard errors. *** and ** denote statistical significance at the $1 \%$ and $5 \%$ levels, respectively.

\section{CONCLUDING REMARKS}

This study sought to predict the financial healthiness of the Indonesian banking system. Banking crises can be costly, not only to governments, but to the public in general. In addition, the consequences of bank crises could cause rising unemployment and possible recessions, as occurred in the Asian economic/financial and global economic crises. The contribution of this paper is to develop a model so that it can be used to detect the probability of banking distress. By doing so, Bank Indonesia could impose effective and appropriate policies to prevent incidences of financial distresses in Indonesia. Thus far, we can conclude that macroeconomic fundamentals (RGDP growth, inflation, stock market performances, net exports and depreciation of domestic currency) and financial soundness (reserve for money bank deposits and ratio of net foreign assets to GDP) are the important factors that can influence the banking stability of the country. As for the bank specific factors, we found that only the inefficiency variable has a significant influence on banks' provision for loan losses, but its sign turned out to be negative which was inconsistent with our expectation.

Thus far, the study has two limitations. First, the credit risk model proposed in this paper is based on our knowledge from the existing empirical literature. As the model is developed for Indonesia case, it may not be applicable to other countries. The underlying reason is that financial regulations across countries differ and the factors affecting credit risk in each country might also differ. Second, the research suffers from severe data limitation. Despite using Bloomberg to obtain reliable information about Indonesia's banking sectors, some of the banks disclosed their financial statements in the past four years only. In other words, the panel dataset used was small and thus, this could generate biased estimations. In conclusion, the results in this study should be treated with caution. 
Yap, G., Modelling the risk of banking system instability in Indonesia using a cross-sectional dependence panel data model

For future research directions, perhaps bootstrapping panel data could be ideal for overcoming data limitation issues. It can be done by re-sampling a new set of data based on the existing information. The re-sampling technique requires only a small number of data and does not need a prior distribution. Furthermore, by resampling, we could identify the 'true' probability distributions of the data and that could generate reliable out-sample dataset to conduct stress-testing.

\section{REFERENCES}

Baltagi, B. H. (2008). Econometric Analysis of Panel Data (4th Edition). Wiley: West Suussex.

Bongini, P., Claessens, S. and Ferri, G. (2000). "The political economy of distress in East Asian financial institutions", Journal of Financial Services Research, 19(1), 5-25.

Demiguc-Kun, Detragiache and Gupta (2006), "Inside the crisis: An empirical analysis of banking systems in distress", Journal of International Money and Finance, 25 (5), $702-718$

Diamond, D. W. And Dybvig, P. H. (1983). "Bank runs, deposit insurance and liquidity", Journal of Political Economy, 91 (3), 401-419.

Dowd, K. (1992). "Models of banking instability: A partial review of the literature", Journal of Economic Surveys, $6(2), 107-132$.

Duttagupta, R. and Cashin, P. (2011). "The anatomy of banking crises in developing and emerging market countries", Journal of International Money and Finance, 30 (2), 354-376.

Goeltom, M. S. (2006). "Indonesia's banking industry: Progress to date", BIS Papers 28, available at www.bis.org/publ/bppdf/bispap280.pdf.

Gorton, G. and Winton, A. (1998), "Banking in transition economies: Does efficiency require instability?", Journal of Money, Credit and Banking, 30, 621-650.

Hadad, M. D., Santoso, W., Santoso, B., Besar, D. S. and Rulina, I. (n.d.). "Macroeconomic stress testing for Indonesian banking system", Working paper, Bank Indonesia. Available at www.business.bham.ac.uk/events/papers/M_Hadad.pdf.

Hoechle, D. (2007). "Robust standard errors for panel regressions with cross-sectional dependence", Stata Journal, 7 (3), 281-312.

Hoggart, G., Reis, R., and Saporta, V. (2002). "Costs of banking system instability: Some empirical evidence", Journal of Banking and Finance, 26 (5), 825-855.

Honohan, P. (2000). "Banking system failures in developing and transition countries: Diagnosis and prediction", Economic Notes, 29 (1), 83-109.

Kalirai, H. and Scheicher, M. (2002), "Macroeconomic stress testing: Preliminary evidence for Austria", Financial Stability Report of Austria. Available at http://www.oenb.at/en/img/fsr3 macroeconomicst tcm16-9484.pdf.

Kaminsky, G. L. (1999). "Currency and banking crises: The early warning of distress", IMF Working Paper, available at www.imf.org/external/pubs/ft/wp/1999/wp99178.pdf.

McLeod, R. H. (2009). "Dealing with bank system failure: Indonesia, 1997-2002", Working paper, The Australian National University, available at http://www.eastasiaforum.org/2009/03/04/indonesia\%e2\%80\%99s-banking-system-under-threats.

Moshirian, F. and Wu, Q. (2009). "Banking industry volatility and banking crises", International Financial Markets, Institutions and Money, 19 (2), 351-370.

Sheng, A. (2009). From Asian to Global Financial Crisis: An Asian Regulator's View of Unfettered Finance in the 1990s and 2000s. Cambridge: New York.

Vo Hagen, J. and Ho, T. (2007). "Money market pressure and the determinants of banking crises", Journal of Money, Credit and Banking, 30 (5), 1037-1066.

Williams, J. and Nguyen, N. (2005). "Financial liberalisation, crisis and restructuring: A comparative study of bank performance and bank governance in South East Asia, Journal of Banking \& Finance, 29 (8-9), 2119-2154. 